\title{
RESEARCH PAPER \\ Experimental evaluation of sediment yield in the first year after replacement of pastures by sugarcane
}

\author{
Cristian Youlton ${ }^{1,2}$ Ana Paula Bragion ${ }^{2}$, and Edson Wendland ${ }^{2}$ \\ 'Pontificia Universidad Católica de Valparaíso, Escuela de Agronomía. Casilla 4-D, Quillota. Chile. \\ ${ }^{2}$ Universidade de São Paulo, Escola de Engenharia de São Carlos, Departamento de Hidráulica e \\ Saneamento. Av. Trabalhador São Carlense, 400 CP 359. CEP: 13566-590. São Carlos SP, Brazil.
}

\begin{abstract}
C. Youlton, A. P. Bragion, and E. Wendland. 2016. Experimental evaluation of sediment yield in the first year after replacement of pastures by sugarcane. Cien. Inv. Agr. 43(3): 374383. Sugarcane cultivation has expanded in south-eastern Brazil in the last decade, mainly for biofuel (ethanol) production. This expansion has occurred on land that was originally covered with pasture and used for livestock production. The purpose of this study is to experimentally determine the impact on runoff and erosion produced by replacing pasture with sugarcane. Runoff plots of $100 \mathrm{~m}^{2}$ were established at a farm in Itirapina, Sao Paulo (SP), Brazil, on a hill with a $9 \%$ slope and sandy soil. An 18-year-old pasture and a new sugarcane plantation were studied. The degrees of runoff and erosion were determined after each rain event for the first year of cultivation. From 1,459 mm of annual rainfall, the pasture had lower runoff than the sugarcane cover ( 40.5 vs $56.1 \mathrm{~mm}$, respectively). Soil erosion under pasture was lower than sugarcane, where the highest values were recorded at the beginning of the rainy season, just after cane planting. In the first year, the results indicate an increase in soil loss of almost 500\% for sugarcane compared to pasture, from 0.58 to $2.58 \mathrm{Mg} \mathrm{ha}^{-1}$ year-1 under our experimental conditions. Overall, changing land cover from pasture to sugarcane increases soil erosion.
\end{abstract}

Key words: Land use change, runoff, sediment granulometry, soil erosion.

\section{Introduction}

In 2013, Brazil produced more than 768 million metric ton of sugarcane, which is equivalent to $40 \%$ of the worldwide production; Brazil was the top sugarcane producer, followed by India and China (FAO, 2015). At the national level, the center of sugarcane production is the state of Sao Paulo, which produced more than 367 million metric ton of sugarcane during the 2013/14 season, equivalent

Received December 10, 2015. Accepted October 5, 2016. Corresponding author: cristian.youlton@pucv.cl to $48 \%$ of the national production and $20 \%$ of the worldwide production during this period (UNICA, 2015). Between 2007 and 2014, the area cultivated with sugarcane for industrial use in the state of Sao Paulo increased from 4.8 to 6.1 million ha, while the area covered with pasture decreased from 7.6 to 5.7 million ha (IEA, 2015). This crop substitution has rapidly increased in the last decade (Adami et al., 2012; Walter et al., 2011) largely due to the use of sugarcane as a raw material for ethanol production (ethanol is used as a biofuel on a large scale in the growing Brazilian automotive industrial zone) and for sugar - both for domestic consumption and for export (Walter et al., 2011). 
Some studies indicate that the expansion of sugarcane production could have a negative environmental impact. According to Martinelli and Filoso (2008), sugarcane production causes erosion by exposing deeply ploughed, bare soil during crop establishment and renewal in cycles of five or six years and between the annual harvest and the planting of new cane. The soil is compacted by heavy machinery for planting and harvesting, which diminishes rain infiltration and increases runoff and erosion (Azadi et al., 2012; Garbiate et al., 2011). Eroded particles produce turbidity in bodies of water, transport agrochemicals and cause the sedimentation of rivers and lakes (Lal, 2001). In the state of Sao Paulo, where the most erosive rainfalls are registered in Brazil (Oliveira et al., 2013), a high susceptibility to erosion is expected.

Few measurements have been taken and few calculations have been made regarding soil loss on sugarcane plantations in the state of Sao Paulo. Martins Filho et al. (2009) evaluated the loss of soil and nutrients $(\mathrm{P}, \mathrm{K}, \mathrm{Ca}$ and $\mathrm{Mg}$ ) in sugarcane plantations using a $65-\mathrm{min}$ rain simulation with different levels of crop stubble coverage $(0,50$ and $100 \%$ ) on an Argisol (Ultisol) soil in the city of Catanduva, SP. An erosion rate of 5.81 $\mathrm{Mg} \mathrm{ha}^{-1}$ year ${ }^{-1}$ was recorded from bare soil, which was reduced to 1.93 and $0.77 \mathrm{Mg} \mathrm{ha}^{-1}$ year $^{-1}$ with 50 and $100 \%$ coverage, respectively. Additionally, a reduction in nutrient loss was recorded with higher stubble coverage. In Guariba, SP, Sousa et al. (2012) quantified the level of erosion just after the harvest period in a soil cultivated with sugarcane by employing a rainfall simulator on a plot with three different slopes $(2.5,5$ and $7 \%)$ and five levels of stubble coverage $(0,25,50,75$ and $100 \%$ ) on a Latosol (Oxisol) soil. They recorded the greatest erosion on the steepest slope with no coverage. The same results were described by Silva et al. (2012) in Pradopolis, SP, by employing a rainfall simulator on a Latosol (Oxisol). Utilizing the Water Erosion Prediction Project (WEPP) model in the Ceveiro watershed, Piracicaba, SP, Sparovek and Schnug (2001) estimated a soil loss of $31 \mathrm{Mg} \mathrm{ha}^{-1}$ year ${ }^{-1}$ with sugarcane, while a loss of $58 \mathrm{Mg} \mathrm{ha}^{-1}$ year ${ }^{-1}$ was calculated using the Universal Soil Loss Equation (USLE) in the same watershed and for the same crop (Weill and Sparovek, 2008). Using the same model, a soil loss of $9.64 \mathrm{Mg} \mathrm{ha}^{-1}$ year $^{-1}$ was estimated during the first year of cultivation on an Argisol (Ultisol) soil in Catanduva, SP (Andrade et al., 2011).

There is little field-tested information about the soil erosion produced in soil either cultivated with sugarcane or covered in pasture in the state of Sao Paulo. According to a study by the Coordination of Integral Technical Assistance (Coordinación de Asistencia Técnica Integral -CATI) developed by Drugowich et al. (2009), the state of Sao Paulo has $3,688,072$ ha of pasture that is used for dairy and mixed livestock, $20 \%$ of which suffers degradation with the appearance of deep furrows and gullies, $60 \%$ has a rolling erosion surface, shallow furrows and/or livestock trails, and only $20 \%$ of this area is correctly managed. Using the USLE, the same author estimated a loss of $9.1 \mathrm{Mg} \mathrm{ha}^{-1}$ year $^{-1}$ in the most degraded areas to a minimum of $0.18 \mathrm{Mg} \mathrm{ha}^{-1}$ year ${ }^{-1}$ (standard deviation of 4.8 and $0.1 \mathrm{Mg} \mathrm{ha}^{-1}$ year $^{-1}$, respectively) totaling $11,219,826 \mathrm{Mg}_{\text {year }}{ }^{-1}$ of eroded soil in the entire state. Another value that was estimated using the USLE in Cunha, SP, reached $28 \mathrm{Mg} \mathrm{ha}^{-1}$ year $^{-1}$ in Latosol (Oxisol) soil covered by pasture (Silva et al., 2005).

Because the previous sugarcane and pasture erosion studies in the state of Sao Paulo had different rain and soil conditions, the results of these studies are not comparable. This lack of comparability prevents an estimation of the real impact of sugarcane replacing pasture on soil erosion. Additionally, the studies that used models were either not calibrated with field measurements of erosion or used isolated measurements with rainfall simulations that do not consider annual variation. As a result, there is no consensus on the scope of the erosion problem caused by crop substitution. Recent studies assess the modification of the physical properties of soils under land use change from pasture to sugarcane, but they do not compare these effects on runoff and soil erosion, and they suggest to evaluate it in 
a Brazilian sugarcane belt (Cherubin et al., 2016; Hunke et al., 2015)

The objective of the present work is to experimentally evaluate sediment production and loss caused by substituting pasture with sugarcane in a Quartzarenic Neosol (Typic Quartzipsamments) soil type that is representative of the western region of the state of Sao Paulo.

\section{Materials and methods}

\section{Study area}

The experiment was installed at a farm in Itirapina, SP (WGS 1984 Coordinates: 23 k 205802 m E 7543956 m S, 790 m elevation, Figure 1). The local climate is at a tropical latitude, which is "Cwa" according to Köppen's classification and is characterized by a hot climate and a dry winter. The hydrologic year runs from October to September, with a rainy period from October to March. The mean annual precipitation between 1961 and 1990 was $1,548 \mathrm{~mm}$ (data from the Sao Carlos weather station that is $20 \mathrm{~km}$ from the study area) (INMET, 2013). The soil is a Quartzarenic Neosol (Typic Quartzipsamments) type with a sandy texture ( $85 \%$ sand, $12 \%$ clay and $3 \%$ silt) that is representative of the western region of the state of Sao Paulo. Measurements were taken on a hill with a $9 \%$ slope and northern exposure.

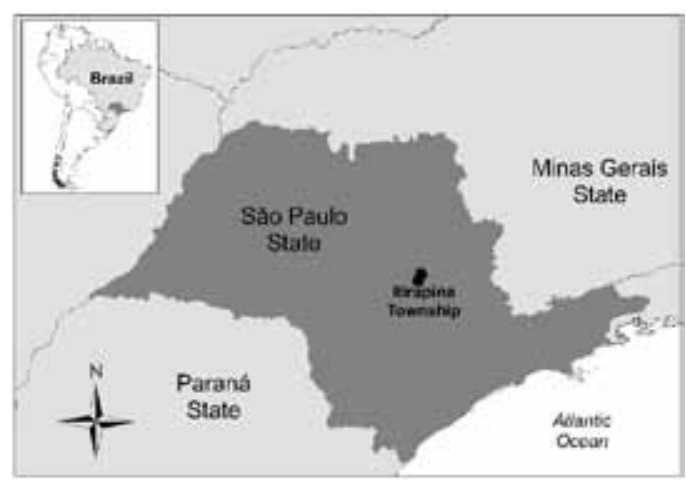

Figure 1. Location of the study area in the township of Itirapina in the state of Sao Paulo, Brazil.

\section{Precipitation record}

The precipitation was recorded in the experimental area with a Campbell automatic weather station, which has a resolution of $0.2 \mathrm{~mm}$ and was programmed to log the precipitation in $10-\mathrm{min}$ intervals. The precipitation measurements started on October 13, 2011, with the installation of the weather station. Precipitation events that were separated by intervals of $6 \mathrm{~h}$ were considered as independent events (Wischmeier and Smith, 1978).

\section{Sediment monitoring}

Runoff plots $\left(20 \times 5 \mathrm{~m}^{2}\right)$ were constructed according to Veiga and Prado (1993) on a new sugarcane plantation in level curves at a distance of $1.5 \mathrm{~m}$ (planted on October 27, 2011, after the first precipitation at the beginning of the rainy season) and on a pasture (Brachiaria decumbens sown for 18 years, height of 5-30 cm) intended for beef cattle (rotated every 30 days, 50 animals in 5 ha for 5 days) with three replicates per treatment (Figure 2). The sugarcane plot was maintained without coverage between rows and by manually controlling weeds. The plots were delimited with metallic edges in the direction of the slope, where the runoff flowed into a pipe and was conveyed to a system of storage tanks.

After every rain event, solid sediments that were retained in the pipe (mainly coarse particles, $2-0.05 \mathrm{~mm}$ in diameter) were recovered with a spatula and kept in labelled plastic bags to be dried and weighed in the laboratory. For each tank that contained runoff and sediment (mainly fine particles in suspension, $<0.05 \mathrm{~mm}$ in diameter), the tank volume was recorded using a high-volume calibration curve that was previously established in the laboratory. The water was vigorously shaken more than 15 seconds to resuspend the sediment. Before sampling, the bottom of the tank was checked for remaining sediments. In the sequence, $1 \mathrm{~L}$ of sample was collected with a labelled plastic bottle. In the laboratory, both the 

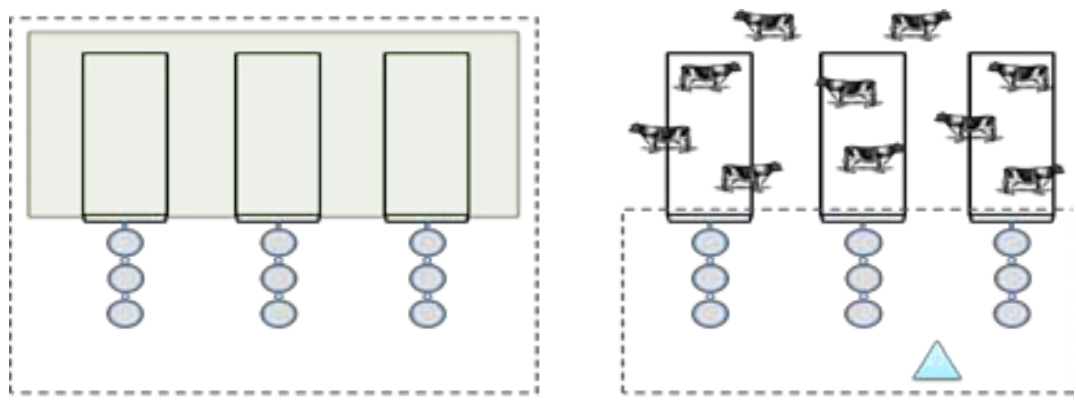

Sugarcane

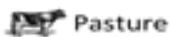

Weather station

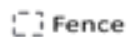

Figure 2. Runoff plot scheme with sugarcane and pasture with livestock forage crops.

sediment samples in suspension and the sediment samples from the pipe were dried in an oven at $105^{\circ} \mathrm{C}$ for $24 \mathrm{~h}$. Sediments from pipes were sieved with a mesh of $0.05 \mathrm{~mm}$ to determine coarse and fine particles proportion. The dry weights of the sediments were determined using a digital scale with a precision of $0.01 \mathrm{~g}$. The laboratory results were calculated according to the total volume of runoff and the total plot area. The erosion monitoring period was designated as the time of planting (October 27, 2011) until the first harvest the following year (November 1, 2012).

\section{Statistical analysis}

The mean of the runoff and erosion were calculated for each event for the three plots with each treatment. A Mann-Whitney nonparametric test was performed using Minitab 16 Statistical Software (Minitab Inc. State College, PA, USA). statistics program to determine if the differences in runoff and sediment production for the different treatments were statistically significant $(\mathrm{P} \leq 0.05)$.

\section{Results}

There were 122 precipitation events that totaled $1,265 \mathrm{~mm}$ of precipitation during the measured period. Only 48 events produced runoff and erosion, accounting for $1,127 \mathrm{~mm}$ of precipitation ( $89 \%$ of the total) (Figure 3$)$. The smallest amount of precipitation that produced runoff and erosion was $6 \mathrm{~mm}$ in $3.7 \mathrm{~h}$ (January 26, 2012), and the greatest amount was $81 \mathrm{~mm}$ in $14.7 \mathrm{~h}$ (December 9, 2011).

The results of the runoff amounts recorded from the plots are presented in Figure 4. The columns corresponding to December 10, 2011, January 11, May 14 and June 8, 2012 each represent two precipitation events that generated runoff; each of these events was quantified as one single event because the interval between them occurred overnight, preventing their collection as independent rain events.

The maximum runoff volume represented $24 \%$ of the precipitation fallen in the pasture plots and $37 \%$ of the precipitation fallen in the sugarcane plots (January 22, 2012). The total annual runoff was $40.5 \mathrm{~mm}$ in the pasture plots and $56.1 \mathrm{~mm}$ in the sugarcane plots, which were equivalent to 3.6 and $5.0 \%$ of the precipitation events generating runoff, respectively. These results indicate that sugarcane produces more runoff than does pasture. The events with high runoff occurred in situations of i) high pluviometry during the rainy period (December 10, 2011 and February 24,2012 ), ii) periods of very frequent rain (January 16 to 22, 2012) or iii) high-intensity events 
(February 12, 2012, April 21, 2012 and October 25, 2012; Figure 4). The runoff values observed in the last situation were very similar. There was a two-month period with no rain, after which time not all precipitation events generated runoff as they would during the full rainy period $(14.4 \mathrm{~mm}$, October 17, 2012).

The results of the amount of erosion produced in each treatment are presented in Figure 5, distinguishing the sediment types as coarse particles (sand) that were collected by the pipe and fine particles (silt and clay) sieved from pipe plus sediments in suspension that were sampled from the tank. As with the runoff, there was less erosion in the pasture plots than in the sugarcane plots. Two exceptions corresponded to the high soil loss values in pasture plots that were recorded in the first two measured events. These high values were due to the disturbance on the soil surface created by installing the plots; this anomaly was also reflected in the runoff values. Sediment production in pasture subsequently diminished drastically to values between 0.00 and $0.02 \mathrm{Mg}$ $\mathrm{ha}^{-1}$, with an equal distribution between coarse and fine particles.

In the sugarcane plots, the rain events up to December 2011 primarily generated coarse sediments, except for two rain events of high depths. Later, there were events with different proportions of coarse and fine sediments. Lastly, a drastic decrease in sediment production in sugarcane was observed beginning in March 2011, with 0.01-0.02 Mg ha', independent of the pluviometry and runoff values. This result indicates that the most critical period for erosion is immediately after sugarcane planting, when the soil is disturbed and unprotected by leaves. After plant growth, interception appears to protect the soil from erosive processes.

A statistical analysis of the results from the MannWhitney test demonstrated significant differences $(\mathrm{P} \leq 0.05)$ between the treatments for both runoff and erosion. During the study period, $0.58 \mathrm{Mg} \mathrm{ha}^{-1}$ year $^{-1}$ of soil was lost in pasture plots, and 2.58
$\mathrm{Mg} \mathrm{ha}^{-1}$ year ${ }^{-1}$ was lost in sugarcane plots (Table 1). These results indicate that sediment production in sugarcane plots is almost 5 times higher than that of cattle pasture plots; coarse particles represent the highest proportion of this loss in both pasture and sugarcane plots. These results seem to be strongly affected by soil disturbance during tillage and sugarcane planting.

Table 1. Total erosion in pasture and sugarcane plots in the first year of cultivation.

\begin{tabular}{lcc}
\hline & $\begin{array}{c}\text { Pasture } \\
\mathrm{Mg} \mathrm{ha}^{-1} \text { year }^{-1}\end{array}$ & $\begin{array}{c}\text { Sugarcane } \\
\mathrm{Mg} \mathrm{ha}^{-1} \text { year }^{-1}\end{array}$ \\
\hline Coarse & 0.36 & 2.09 \\
Fine & 0.22 & 0.49 \\
Total & 0.58 & 2.58 \\
\hline
\end{tabular}

\section{Discussion}

The highest runoff values occurred during heavy, prolonged or frequent rainfall events. The runoff values produced by intense events were similar for pasture and sugarcane plots. Garbiate et al. (2011) used a rainfall simulator at a sugarcane plantation, from which they determined that the runoff under high rate and/or long time rainfall is almost completely unaffected by the coverage and management of the soil because the soil has a limited capacity to absorb water. By contrast, most precipitation events occurring at the beginning of the rainy season do not generate runoff because the soil is dry and absorbs all the precipitation. However, this behavior is strongly affected by the soil texture, which controls the water dynamics in the soil profile.

In pasture plots, the first two rain events had the highest runoff and erosion values due to the surface disturbance during plot construction, leaving the soil nearly without vegetation coverage close to the pipe. Consequently, the first two events were the only events in the entire study period with runoff exclusively in pasture plots. This anomaly is also clearly visible in the erosion results, with 
PRECIPITATION

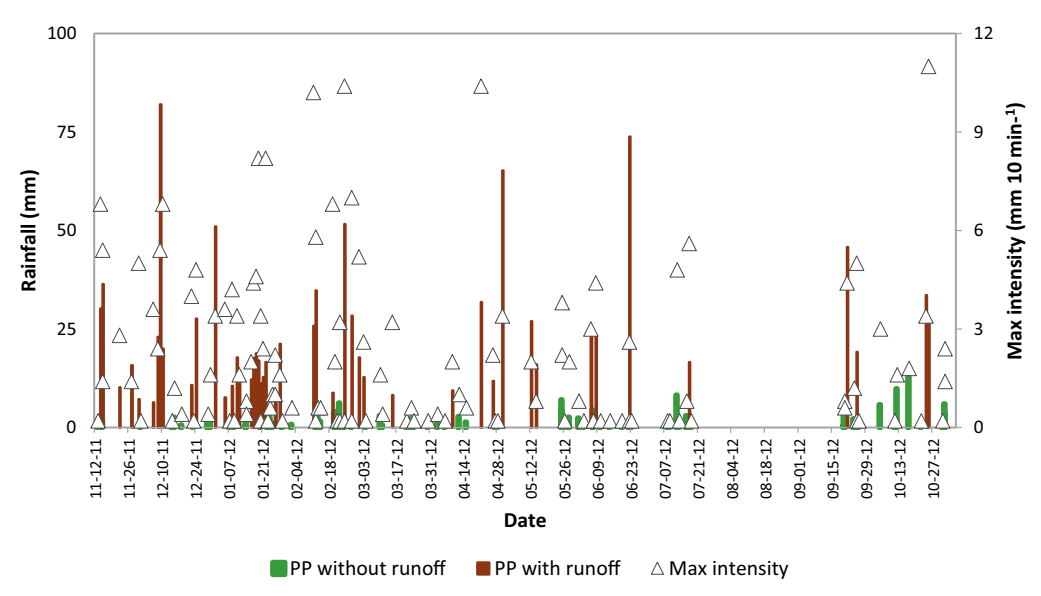

Figure 3. Precipitation $(\mathrm{mm})$ events and intensity $\left(10 \mathrm{~mm} \mathrm{~min}^{-1}\right)$. Green bars indicate events with no observed runoff.

a) Pasture runoff

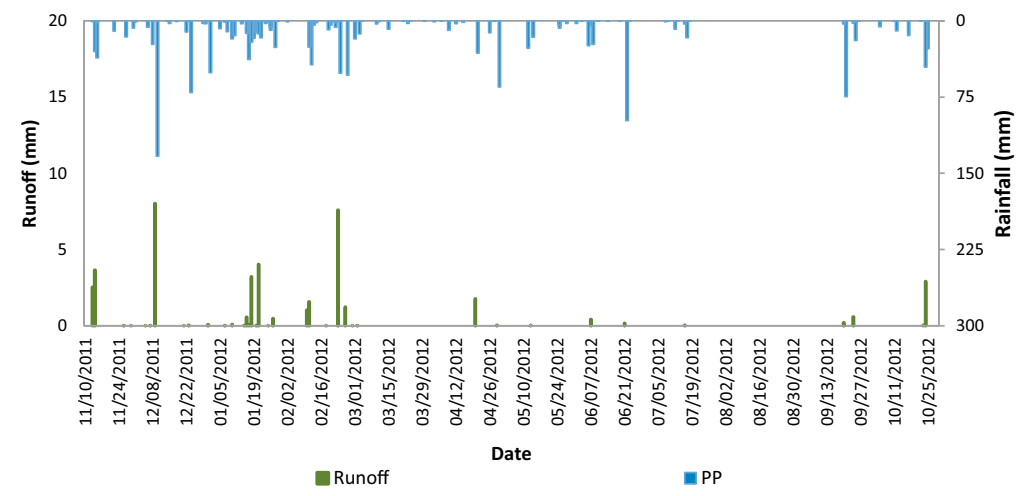

b) Sugarcane runoff

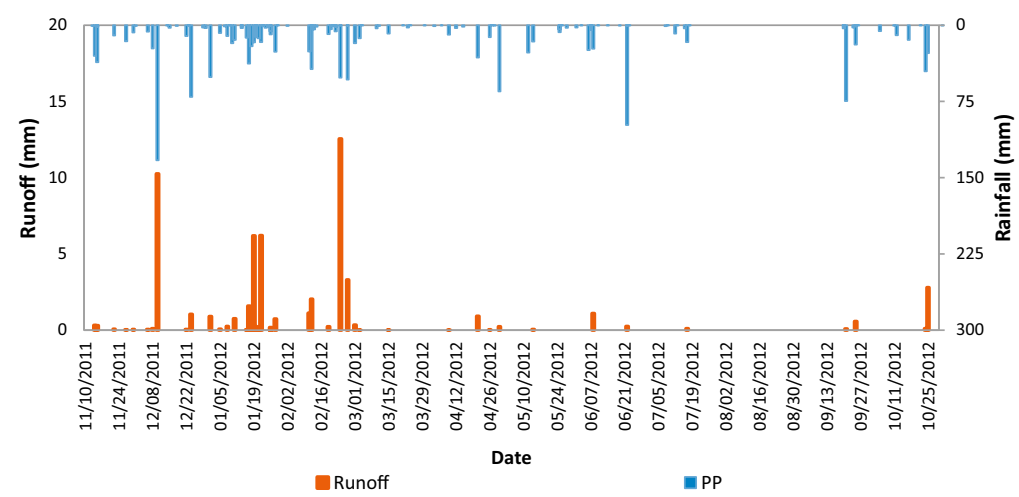

Figure 4. Runoff observed for a) pasture and b) sugarcane. 
a) Pasture soil erosion

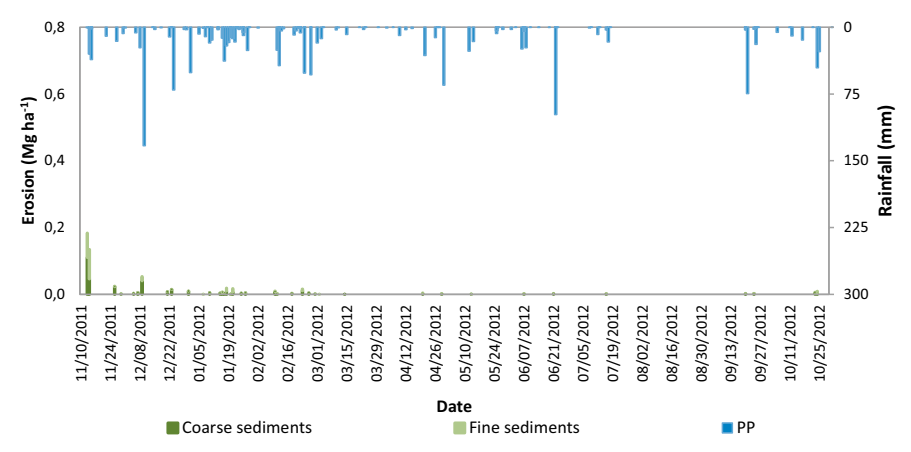

b) Sugarcane soil erosion

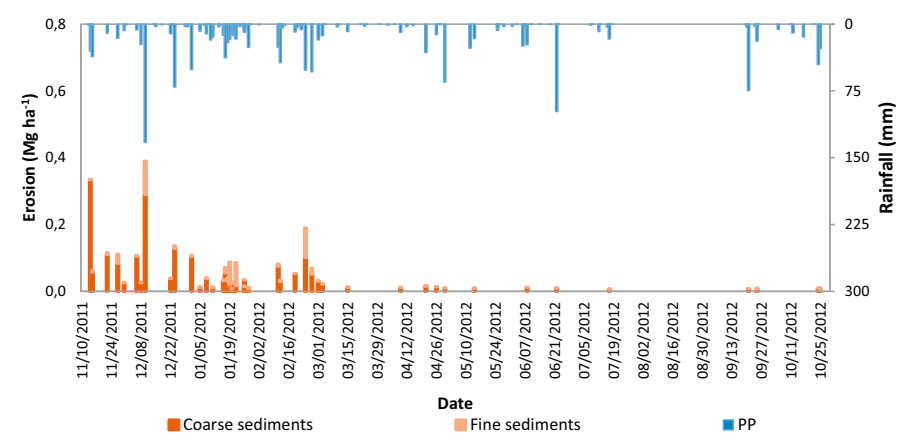

Figure 5. Erosion observed for each treatment: a) pasture and b) sugarcane. Sediment size (coarse or fine) per event is indicated in each column.

the pasture registering the highest sediment production values, surpassing even the sugarcane results for one event. Therefore, these first two events should be excluded from the final pasture results; with this modification, the soil loss with pasture coverage would be $0.27 \mathrm{Mg} \mathrm{ha}^{-1}$ year ${ }^{-1}$.

In the sugarcane plots, the rain events that occurred before December 2011 generated mostly coarse sediments with reduced runoff. This situation can be explained by the disturbed condition of the soil after being ploughed, which favors the transport of sediments by splash-saltation near the pipe after the impact of the rain (Morgan, 2005; Toy et al., 2002). This low runoff can also be explained by a porous soil surface after plough, increasing infiltration and the presence of furrows in a level curve, which intercept and infiltrate the runoff while retaining fine sediments avoiding carry-out along the plots.
Since January 2012, soil sediments under sugarcane increase fine sediments proportion, conjugated with high runoff values. This suggests that events that have high levels of fine particles, which are higher than the percentage of silt and clay found in the soil, indicate the transport of sediments along the plot due to high runoff values. This effect is due to the silting of the furrows, which reduces the interception of the runoff and diminishes their capacity to retain sediments, in addition to the pluviometric conditions that were discussed previously. The formation of small canals was observed in the field, which collapse the furrows on the level curve, allow the movement of runoff loaded with sediment. Another soil factor that favors runoff is the superficial seal of clay pores (soil crusting), which diminishes the capacity of the soil for infiltration and reduces superficial roughness. These findings are in agreement with the descriptions of Bezerra and Cantalice (2006), 
Brandão et al. (2007), Tomasini et al. (2010) and Garbiate et al. (2011). Sediment yield under sugarcane decreased since March 20012, probably due to soil coverage by leaves (not measured) and rainfall reduction during the dry season. In contrast, under pasture, the soil erosion reduced since early December 2011.

Although our experiment pattern agrees with previous assessments carried out with plots, our absolute values are quite different due to our larger study scale (plots of $100 \mathrm{~m}^{2}$, under natural rainfall regime). In Brazil, Thomaz and Vestena (2012) found that increasing plot size reduces runoff results because the surface is more complex, while soil erosion values are comparable; they note that $100 \mathrm{~m}^{2}$ erosion plots are acceptable as a representative area (Hudson, 1997).

The main conclusions are as follows. Runoff is produced during precipitation events of high depth, high intensity or high frequency of events.
During a heavy rain event, there is no difference between the levels of runoff recorded in sugarcane and pasture plots. In the first year, after the replacement of pasture by sugarcane on sandy soil and tropical climate conditions, soil erosion rates increase almost $500 \%$, from 0.58 to 2.58 $\mathrm{Mg} \mathrm{ha}^{-1}$ year $^{-1}$, under our experimental conditions.

\section{Acknowledgements}

The authors would like to thank the Foundation for Research Support of the State of São Paulo (Fundação de Amparo à Pesquisa do Estado de São Paulo- FAPESP, Brazil) for funding the present study (Proceso 2010/00251-5), the National Council for Scientific and Technological Development (Conselho Nacional de Desenvolvimento Científico e Tecnológico - CNPq) for the doctoral fellowship of the first author and the Arruda Botelho Institute (IAB) for facilitating the study area and installations at the San José farm in Itirapina, SP.

\section{Resumen}

C. Youlton, A. P. Bragion y E. Wendland. 2016. Evaluación experimental de la producción de sedimentos durante el primer año después del reemplazo de pradera por caña de azúcar. Cien. Inv. Agr. 374-383. El cultivo de caña de azúcar se convirtió en el cultivo de mayor expansión durante los últimos años en el sudeste de Brasil, ya que se utiliza como materia prima para la producción de biocombustible (etanol). En el estado de Sao Paulo, la expansión ocurre principalmente en áreas que eran ocupadas por praderas. La sustitución tiene impactos sobre la escorrentía y la erosión de suelos debido a los cambios en la cobertura y las prácticas agrícolas. El objetivo del presente estudio es cuantificar experimentalmente el impacto en la escorrentía y erosión de suelos causado por la sustitución de pradera por caña de azúcar. Se construyeron parcelas de escorrentía $\left(100 \mathrm{~m}^{2}\right)$ en una hacienda del municipio de Itirapina-SP, sobre una ladera con $9 \%$ de pendiente y suelo arenoso. Una pradera con pastos sembrados hace más de 18 años y una plantación nueva de caña de azúcar fueron evaluados, con tres repeticiones para cada cobertura. La escorrentía y erosión de suelos fueron medidas después de cada evento de lluvia durante el primer año desde la plantación de caña de azúcar. Se registraron $1.459 \mathrm{~mm}$ de precipitaciones, donde pradera presentó menos escorrentía que caña de azúcar (40,5 vs 56,1 mm respectivamente). La erosión en pradera fue mínima comparada con caña de azúcar, alcanzando los mayores valores en el inicio de la temporada lluviosa, justo después de la plantación. Los resultados indican una pérdida de suelo de $0,58 \mathrm{Mg} \mathrm{ha}^{-1}$ año ${ }^{-1}$ en pradera a $2,58 \mathrm{Mg} \mathrm{ha}^{-1}$ año $^{-1}$ en caña de azúcar. El cambio de cobertura desde pradera a caña de azúcar aumenta la erosión de suelo.

Palabras clave: Cambio de uso de suelo, erosión de suelo, escorrentía, granulometría de sedimentos. 


\section{References}

Adami, M., B.F.T. Rudorff, R.M. Freitas, D.A. Aguiar, L.M. Sugawara, and M.P. Mello. 2012. Remote sensing time series to evaluate direct land use change of recent expanded sugarcane crop in Brazil. Sustainability 4:574-585.

Andrade, N.S.F.d., M.V. Martins Filho, J.L.R. Torres, G.T. Pereira, and J. Marques Júnior. 2011. Impacto técnico e econômico das perdas de solo e nutrientes por erosão no cultivo da cana-de-açúcar. Engenharia Agrícola 31:539-550.

Azadi, H., S. de Jong, B. Derudder, P. De Maeyer, and F. Witlox. 2012. Bitter sweet: How sustainable is bio-ethanol production in Brazil? Renewable and Sustainable Energy Reviews 16:3599-3603.

Bezerra, S.A., and J.R.B. Cantalice. 2006. Erosão entre sulcos em diferentes condições de cobertura do solo, sob cultivo da cana-de-açúcar. Revista Brasileira de Ciência do Solo 30:565-573.

Brandão, V.d.S., D.D.d. Silva, H.A. Ruiz, F.F. Pruski, C.E.G.R. Schaefer, M.A. Martinez, and E.O. Silva. 2007. Perdas de solo e caracterização física e micromorfológica de crostas formadas em solos sob chuva simulada. Engenharia Agrícola 27:129-138.

Cherubin, M.R., D.L. Karlen, A.L.C. Franco, C.A. Tormena, C.E.P. Cerri, C.A. Davies, and C.C. Cerri. 2016. Soil physical quality response to sugarcane expansion in Brazil. Geoderma 267:156-168.

Drugowich, M.I., S. Savastano, and S.A.A.d. Lima Savastano. 2009. Erosão em pastagens sob pecuária leiteira e mista no estado de São Paulo. CATI, Sao Paulo, Brasil. 14 pp.

FAO. 2015. FAOSTAT Production Crops 2013. FAOSTAT - Countries by commodity, 2013. FAO. Available online at: http://www.fao.org/ faostat/ (Website accesed: november 23, 2015).

Garbiate, M.V., A.C.T. Vitorino, B.A. Tomasini, A.C. Bergamin, and E. Panachuki. 2011. Erosão em entre sulcos em área cultivada com cana crua e queimada sob colheita manual e mecanizada. Revista Brasileira de Ciência do Solo 35:2145-2155.

Hudson, N.W. 1997. Medición sobre el terreno de la erosión del suelo y de la escorrentía. FAO, Roma, Italia. 147 pp.
Hunke, P., R. Roller, P. Zeilhofer, B. Schröder, and E.N. Mueller. 2015. Soil changes under different land-uses in the Cerrado of Mato Grosso, Brazil. Geoderma Regional 4:31-43.

IEA. 2015. Serie Informações Estadísticas da Agricultura SP. Anuário Instituto de Economía Agrícola 2014. Instituto de Economía Agrícola, Sao Paulo, Brasil. 118 pp.

INMET. 2013. Normais Climatológicas do Brasil 1961-1990. Available online at http://www. inmet.gov.br/portal/index.php? $\mathrm{r}=\mathrm{clima} /$ normaisClimatologicas (Website accesed: may 21, 2013).

Lal, R. 2001. Soil degradation by erosion. Land Degradation \& Development 12:519-539.

Martinelli, L., and S. Filoso. 2008. Expansion of sugarcane ethanol production in Brazil: environmental and social challenges. Ecological Applications 18:885-898.

Martins Filho, M.V., T.T. Liccioti, G.T. Pereira, J. Marques Júnior, and R.B. Sanchez. 2009. Perdas de solo e nutrientes por erosão num Argissolo com resíduos vegetais de cana-de-açúcar. Engenharia Agrícola 29:8-18.

Morgan, R.P.C. 2005. Soil Erosion and Conservation. 3th ed. Wiley, Malden, MA, USA. 316 pp.

Oliveira, P.T.S., E. Wendland, and M.A. Nearing. 2013. Rainfall erosivity in Brazil: A review. CATENA 100:139-147.

Silva, A.M.d., M. Ranzini, M.E.G. Guandique, F.C.S. Arcova, and V.d. Cicco. 2005. Estudo Integrado do processo erosivo numa microbacia experimental localizada no município de Cunha - SP. Revista Geociências 24:43-53.

Silva, G.R.V.d., Z.M.d. Souza, M.V. Martins Filho, R.S. Barbosa, and G.S.d. Souza. 2012. Soil, water and nutrient losses by interrill erosion from green cane cultivation. Revista Brasileira de Ciência do Solo 36:963-970.

Sousa, G.B., M.V. Martins Filho. and S.S.R. Matias. 2012. Perdas de solo, matéria orgânica e nutrientes por erosão hídrica em uma vertente coberta com diferentes quantidades de palha de canade-açúcar em Guariba - SP. Engenharia Agrícola 32:490-500. 
Sparovek, G., and E. Schnug. 2001. Temporal erosion-induced soil degradation and yield loss. Soil Sci. Soc. Am. J. 65:1479-1486.

Thomaz, E.L., and L.R. Vestena. 2012. Measurement of runoff and soil loss from two differently sized plots in a subtropical environment (Brazil). Earth Surface Processes and Landforms 37:363-373.

Tomasini, B.A., A.C.T. Vitorino, M.V. Garbiate, C.M.A.d. Souza, and T. A. Sobrinho. 2010. Infiltração de água no solo em áreas cultivadas com cana-de-açúcar sob diferentes sistemas de colheita e modelos de ajustes de equações de infiltração. Engenharia Agrícola 30:1060-1070.

Toy, T.J., G.R. Foster, and K.G. Renard. 2002. Soil Erosion: Processes, Prediction, Measurement, and Control. John Wiley \& Sons, New York, USA. 352 pp.

ÚNICA - União da Indústria de Cana-de-Açúcar. 2015. Relatório final safra 2013/2014 - região centro-sul do Brasil. 32 pp.
Veiga, M.d., and W.L.d. Prado. 1993. Manual para la instalación y conducción de experimentos de pérdidas de suelos. FAO. Santiago, Chile. 36 pp.

Walter, A., P. Dolzan, O. Quilodrán, J.G. de Oliveira, C. da Silva, F. Piacente, and A. Segerstedt. 2011. Sustainability assessment of bio-ethanol production in Brazil considering land use change, GHG emissions and socio-economic aspects. Energy Policy 39:5703-5716.

Weill, M.d.A.M., and G. Sparovek. 2008. Estudo da erosão na microbacia do Ceveiro (Piracicaba, SP): I - Estimativa das taxas de perda de solo e estudo de sensibilidade dos fatores do modelo EUPS. Revista Brasileira de Ciência do Solo 32:801-814.

Wischmeier, W.H., and D.D. Smith. 1978. Predicting rainfall erosion losses: a guide to conservation planning. Handbook No. 537. USDA Agricultural Service, Washington DC, USA. 58 pp. 